\title{
A Perspective Study on Oral-Fecal Transmission of COVID-19, its Prevention and Management
}

\author{
Abdullah Abdullah¹, Shah Faisal ${ }^{2}$, Hasnain Jan²,3 ${ }^{2,}$ Rimsha Zainab ${ }^{4}$, Anees ur Rahman ${ }^{5}$, Ayyaz \\ $\mathrm{Khan}^{3}$, Baseerat Bibi ${ }^{6}$, Hania Ishaq
}

1. Department of Microbiology, Abdul Wali Khan University, Mardan, KPK, Pakistan.

2. Department of Biotechnology, Bacha Khan University, Charsadda, KPK, Pakistan.

3. Department of Biotechnology, Quaid-i-Azam University, Islamabad, 45320, Paksitan.

4. Department of Botany, Hazara University, Mansehra, KPK, Pakistan.

5. Department of Microbiology, Abasyn University Peshawar, KPK, Pakistan.

6. Department of Zoology, Shaheed Benazir Bhutto Women University, Peshawar, KPK, Pakistan.

7. Department of Botany, PMAS Arid Agriculture University, Rawalpindi, Islamabad, Pakistan.

\author{
Corresponding author: \\ Hasnain Jan \\ Department of Biotechnology, \\ Bacha Khan University, \\ Charsadda, KPK, Pakistan. \\ Email: hasnainjan@bs.qau.edu.pk
}

\begin{abstract}
The novel coronavirus outbreak arose in Wuhan, China in Dec, 2019. It is declared the 6th public health emergency by the WHO and named as COVID-19. SARS-CoV-2 is non-segmented positive sense ssRNA virus, belongs to the Coronaviridae under the Nidovirales and spread largely in human beings and other mammals. Person to person, airborne and surface transmission is common, the the virus gets entered to host through nose, mouth, eyes, food, water and feces. An infected patient can transmit the virus to 2.2 healthy individuals. A patient in the US showed gastrointestinal symptoms vomiting, nausea and passed loose stools. Later the patient declared positive for SARS-CoV-2 based on viral detection in stools and respiratory samples. The gastrointestinal symptoms like diarrhea, nausea, vomiting, abdominal discomfort and detection of SARS-CoV-2 in stools of infected and recovered patients indicates potential oral-fecal transmission route, it could be potential risk for the spread of COVID-19. The flatus is gas produced by aerophagia or bacterial fermentation in intestine and expelled out through esophagus or anus. It consists of Hydrogen, Oxygen, Nitrogen, Carbon dioxide and Methane, their percentage composition is 99\%. Previous study showed that bacteria can transmit through bare-bottom farting. The gastrointestinal manifestation and possible oral-fecal transmission, the flatulence could be the risk of transmission for COVID-19. Personal hygiene must be adapted to prevent the spread of disease.
\end{abstract}

Keywords: Flatulence; Aerophagia; COVID-19; Transmission; SARS-CoV-2; Farting; Management

Citation: Abdullah A, Faisal S, Jan H, Zainab R, Rahman A, Khan A, Bibi B, Ishaq H. A Perspective Study on Oral-Fecal Transmission of COVID-19, its Prevention and Management. International Cardiovascular Forum Journal 2020;20:10-15.DOI: 10.17987/icfj.v20i0.695

\section{Introduction}

The novel coronavirus outbreak arose in Wuhan China in Dec 2019. As of April 27, 2020, a total 2.98 million positive cases and 207 thousand deaths have been registered worldwide. The mortality rate of SARS-CoV-2 is less than SARS-CoV and MERS. According to the China CDC, by Feb 16, 2020, there had been 70641 confirmed cases of COVID-19 and 1772 deaths, with an average mortality rate of about $2.5 \%[1,2]$ which is less than mortality rate of the MERS (34.40\%) \& SARS-CoV (9.19\%) [3], figure 1.
Recent studies revealed that respiratory symptoms of COVID-19 including fever cough and dyspnea are like SAR-CoV outbreak and MERS. The frequency of typical gastrointestinal features like vomiting, nausea, diarrhea, and abdominal aches significantly differs between distinct studied populations, however these symptoms are mild and followed by more severe respiratory signs and symptoms [4]. Evidences are there from past studies of SARS indicating the gastrointestinal tropism of SARS-CoV was confirmed by viral presence in stools and biopsy of infected and recovered individuals, may give partial explanation for the 


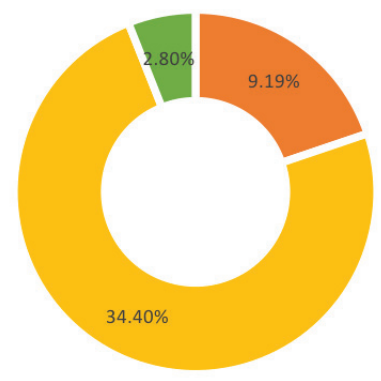

- SARS-CoV-1 = MERS-CoV = SARS-CoV-2

Figure 1. Mortality rate of SARS-CoV-1, SARS-CoV-2 and MERS coronavirus

gastrointestinal manifestation and dissemination of SARS [5]. It was confirmed by the 2-day history of a patient in the US, at the time of admission vomiting and nausea were reported, and on the second day he passed a loose stool in hospital. Later the patient declared positive of SARS-CoV-2 on the basis of viral detection in stools and respiratory specimens [6]. 2019$\mathrm{nCoV}$ nucleic acids were also detected in salivary samples of diseased individuals rather than aspirate from naso-pharynx, later the decline viral abundance was also reported in saliva after attending hospital [7].

Taking into consideration a number of growing clinical evidences revealed that digestive system may assist as a substitute way for infection in individuals in proximity with untamed and suffered animals. However, the individuals with mild symptoms or asymptomatic have been ignored in former studies. So doctors should take care and investigate the individuals with mild and primarily gastrointestinal manifestations and note the time span of infection to late viral transformation. The cases of severe acute respiratory syndrome are increasing day by day and the whole world is confronting the pandemic Covid-19. Shown in figure 2.

\section{Transmission}

As the first case reported was in Wuhan China so it is said that this virus came from Hunan Seafood Wholesale Market situated in Wuhan, but there is still no evidence. Human to human transmission is common as according to the CDC and WHO, it was obvious that close contact is the major facilitator to transmit COVID-19 infection. The virus travels up to one metre in the air and contracted by the person who is in close proximity to the infected person. From the analysis of the investigations and research conducted by the China CDC, the incubation period could be 3 to 7 days or may be up to 2 weeks [5]. It was also concluded from the data that within every seven days this novel SARS-CoV-2 doubles its progeny and the reproduction number is $R 0$ is 2.2 , simply each patient can transmit the infection to an extra 2.2 individuals shown in figure 3 . On the other hand, if we compare SARS-CoV with SARS-CoV-2 the Reproduction rate of the SARS-CoV epidemic were approximately 3 in 2002-2003 [8].

\section{Person to Person Transmission}

Experts believe that all routes of transmission for CoVID-19 are possible but in novel coronavirus the person to person transmission is very common [9]. This can happen in many ways: when an infected person with corona virus coughs, talks or sneezes in a close proximity with healthy individuals of about 6 feet distance [10]. The healthy one gets the virus into his lungs by nose or mouth and gets infected. Recent studies revealed that $\mathrm{nCoV}-19$ can live in the air for up to 3 hours [11]. This virus floating in the air and contaminates the air for healthy individuals. Another way of transmission is surface transmission in which a patient coughs or sneezes on. The virus can live on plastic and stainless-steel surfaces for up to 2-3 days.

\section{Oral-Fecal Transmission}

Studies also suggest that the fecal-oral route could be a potential route of transmission. The virus has been detected in stools of infected patients [12]. Attending a washroom without hand washing spreads the virus. Symptomatic patients often spread the virus. But asymptomatic cases are alarming due to no sign of symptoms and act as a free vector, they don't know

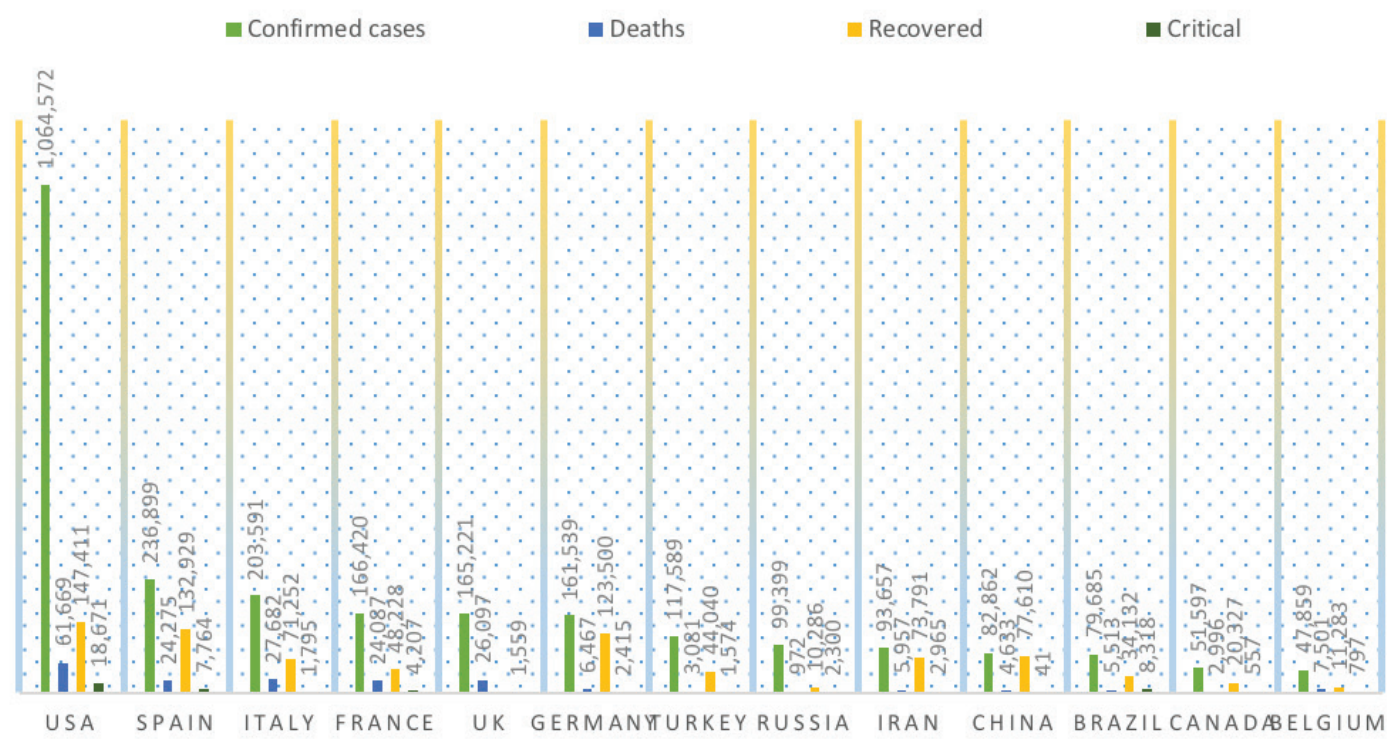

Figure 2. As of March 30, 2020. These are the top 14 Countries of the world having highest number of confirmed cases. 


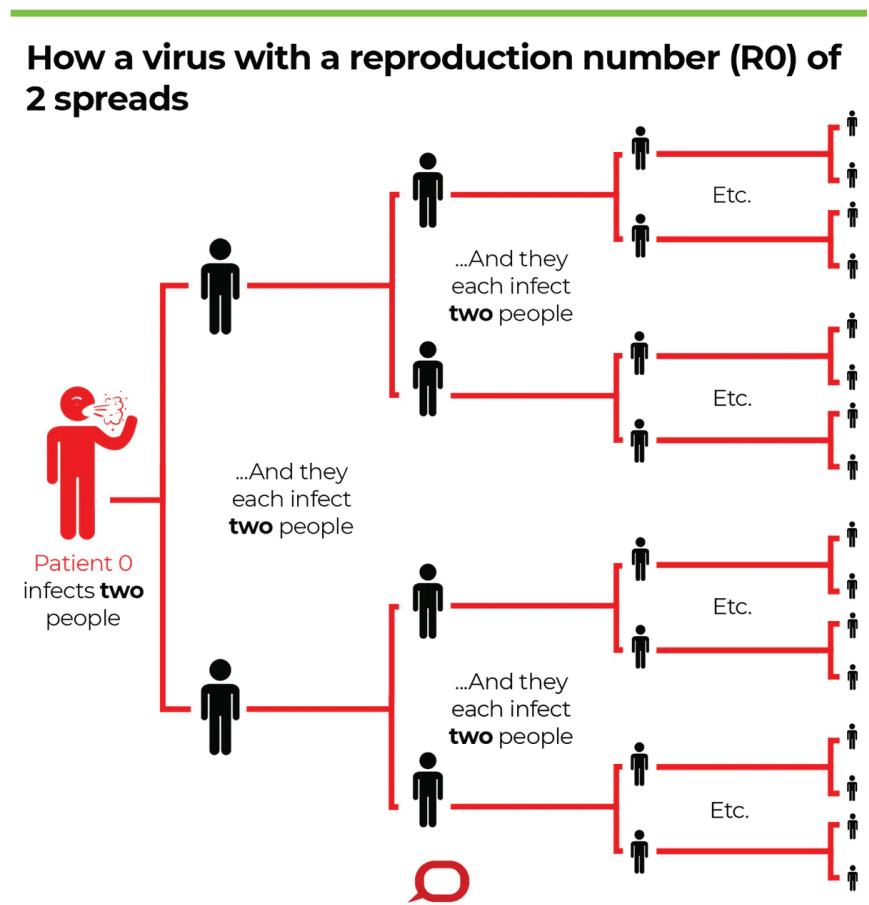

Figure 3. Reproduction number and transfer rate of COVID-19 (Source: https://ivoryembassy.com/blog/r0-of-covid-19)

they've been infected and pass the virus to others easily [13]. Pre-symptomatic spread passes virus to others before noticing any signs and symptoms of infection. Community spread is also common in which persons didn't know from where and whom they were infected [14].

\section{Flatulence}

State of being flatulent is called Flatulence. Medically gas generated in the stomach or in large and small bowels is termed as Flatus [15]. These are the gases generated in intestine due to digestive problems or inhaled air during eating food, thus Flatus is not totally produced in the stomach or Gl tract but a proportion of environmental air oxygen and nitrogen may be swallowed can cause intestinal gas [16]. Volume or frequency of flatus differs between individuals, but it's common to pass flatus and the feculent odor is normal for intestinal gas [17]. By the pressure of muscular layer surrounding the intestine the Flatus is brought to the rectum to be expelled out. The blowing noise of flatulence is created by the anal aperture and buttocks acting together in a manner similar to wind instrument (embouchure) that produce sound. The sound and the odor both are considered root of shame, anger or comedy [18]. Common symptoms linked to intestinal gas, the primary symptoms linked to intestinal gas are; aches in the anal and area around abdomen, a bloated feeling and abdominal discomfort, excessive flatus volume and smell, lack of voluntary control over gas. Moreover, sometimes belching or eructation (act of air expelling from the stomach via mouth) also known as burping is considered as flatulence [19]. Furthermore, in health disorders like lactose intolerance, irritable bowel syndrome and celiac disease, the excessive flatus can be a sign [20].

\section{Mechanism of Production of Flatus}

Bacterial fermentation in the gastrointestinal tract is the main production source of flatus, released as a byproduct especially during the fermentation occurring in colon [21]. There are rare

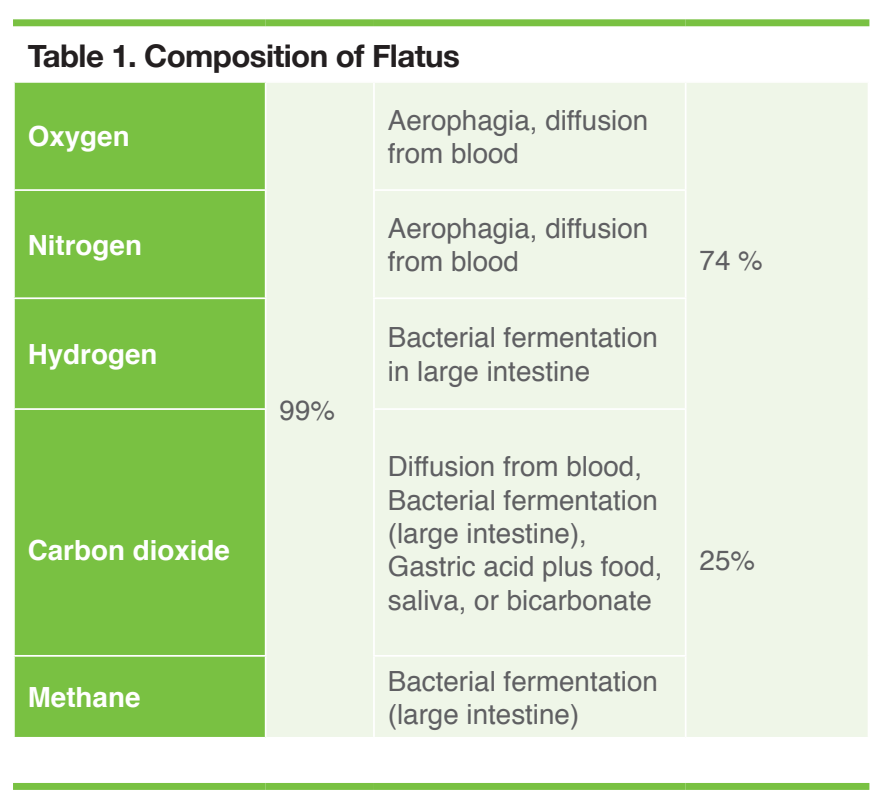

reports of aerophagia causing intestinal gas [22]. The following four events are responsible for the production of naturally occurring gas in gastrointestinal tract. Aerophagia, Gastric acid interaction with alkaline food, pancreatic bicarbonate and saliva, Diffusion of Oxygen, carbon dioxide and nitrogen from blood, Bacterial metabolism, and fermentation process. The produced Gases are removed by either diffusion into blood and consumed by bacteria or expelled out through esophagus or anus. Primarily aerophagia is considered for gas production in Gl tract during meal environmental air is swallowed [23]. UCT (ultrafast computed tomography) in humans revealed that $17 \mathrm{ml}$ of air gets swallowed with drinking $10 \mathrm{ml}$ of water [24]. Every day large amount of air reaches to the stomach with given food (solid or liquid) that is taken into the mouth all day. The N2 component of swallowed air is then passed through rectum, if not blenched25.

Vigorous exercise and rapid eating habit increase the risk of aerophagia however some air also ingests with the propulsions of bolus through pharynx. Within 15 to 35 minutes flatus is produced in the stomach by aerophagia [25]. Gases can travel at velocity or speed of up to $10 \mathrm{~cm} / \mathrm{sec}$ through the gasterointestinal tract however the intestinal transit time is longer for liquids and solids compared to gasses. Production of $\mathrm{CO} 2$ occurs in the stomach by the interaction of HCL with alkaline food, saliva and bicarbonates present in pancreatic juice. Swallowed air plus variable quantities of $\mathrm{CO} 2$ constitute belched air however bacterial fermentation can also produce large amounts of gas in the colon. Fiber, poorly digestible protein, carbohydrates, mucin, bile acids are the substrates for bacterial fermentation to produce gas. Non-digestible oligosaccharides raffinose, stachyose, verbacose are more likely to generate more gas in the intestine [26]. Composition of flatus consists of gasses over $99 \%$ of the whole composition including hydrogen, oxygen, nitrogen, carbondioxide and methane gas, these gasses are non-smelly in nature [27]. Patients with problems of intense intestinal gas mainly consists of N2 [28]. Nitrogen and oxygen are not produced in the $\mathrm{Gl}$ tract but it is from environmental air. $\mathrm{H} 2, \mathrm{CO} 2$ and $\mathrm{CH} 4$ are generated in the bowel and constitute $74 \%$ of the whole volume of flatus (28) and $25 \% \mathrm{O} 2$ and N2 as shown in table 1. Flatus contains proper amounts of methane and hydrogen because of their flammable nature [29]. But not all humans produce methane 
containing flatus. For example, Miller et al, conducted study on 9 feces samples only 5 of them having archaea which is capable of generating $\mathrm{CH} 4$ gas [30]. As Archaea oxidizing hydrogen into methane gas can enhance the metabolic capability to absorb fatty acids from food, thus presence of methane in human farts may correlate with obesity [26].

The noxious smell of flatus in humans and animals strongly correlates with $\mathrm{H} 2 \mathrm{~S}$ concentration [25]. The trace compounds present in amount less than $1 \%$ gives smell to flatus. Ammonia, indole, skatole and short chain fatty acids cause smell similar to flatus. Volatile sulfur compounds are the main contributor to the smell [26]. Methanethiol, hydrogen sulfide, dimethyl sulfide, di and trisulfide are found in flatus. Smell of volatile indole and skatol are noxious but do not contribute to flatus smell.

It is revealed by Levitt et al study that H2S, methyl mercaptan and dimethyl sulfide concentration have correlation with perceived bad smell of flatus respectively, subjecting pinto beans as a diet to stimulate flatus production [31]. It is also reported that methanethiol is the contributor to the flatus smell in those patients whose specific diet is not altered [32]. It has now been revealed that methanethiol and $\mathrm{H} 2 \mathrm{~S}$, are present in human flatus in concentrations above thresholds which increase the noxicity in smell [33]. Such smell can also be caused by bacterial micro flora in feces through fermentation in rectal canal. Sulfur containing amino acids increases the smell of flatus significantly.

\section{Does Flatulence present any Risk of Transmission for COVID-19?}

Recently on Friday, 17th April, Dr. Norman Swan stated that bare-bottom farting should be avoided near each other as it could potentially spread the virus, he told in a live podcast "Coronacast". Dr. Andy Tagg tweeted a related question "can the bottom-based emissions of someone with coronavirus be silent and deadly?" subject to farts as a risk of transmission for COVID-19. A hot discussion started on it and Tagg gave information about Gl tract and flatulence. Tagg concluded that the SARS-CoV-2 could potentially spread through farts. He linked his conclusion with the Tang et al study that showed SARS-CoV-2 virus can be spread through feces and it has been detected in asymptomatic patients up to 17 days past the point of exposure [33]. A well-known epidemiologist Dr. Aaron E. Glatt wrote an email to The New York Post stating that studies revealed that there is a significant percentage of covid-19 patients who have gastrointestinal symptoms [34]. So, farts could transmit it but there is no published data on it to confirm. However, among different study populations the incidence of nausea, diarrhea, vomiting and other abdominal discomforts varies significantly with early mild onset of respiratory symptoms [35]. Former studies of SARS-CoV indicated and verified viral detection in biopsy and stools specimen even in discharged patients [36] which may provide partial explanation that the virus exists in stools and could be transmitted through flatulence. Recently two Chinese laboratories reported live SARS-CoV-2 in stools samples of infected patients.

Dr Karl Kruszelnicki designed his experiment to know whether the farting can contaminate the sterilized environment of operation theatres or not. For this he contacted to a microbiologist Mr. Luke Tennent and set up an experiment. He took two petri dishes and

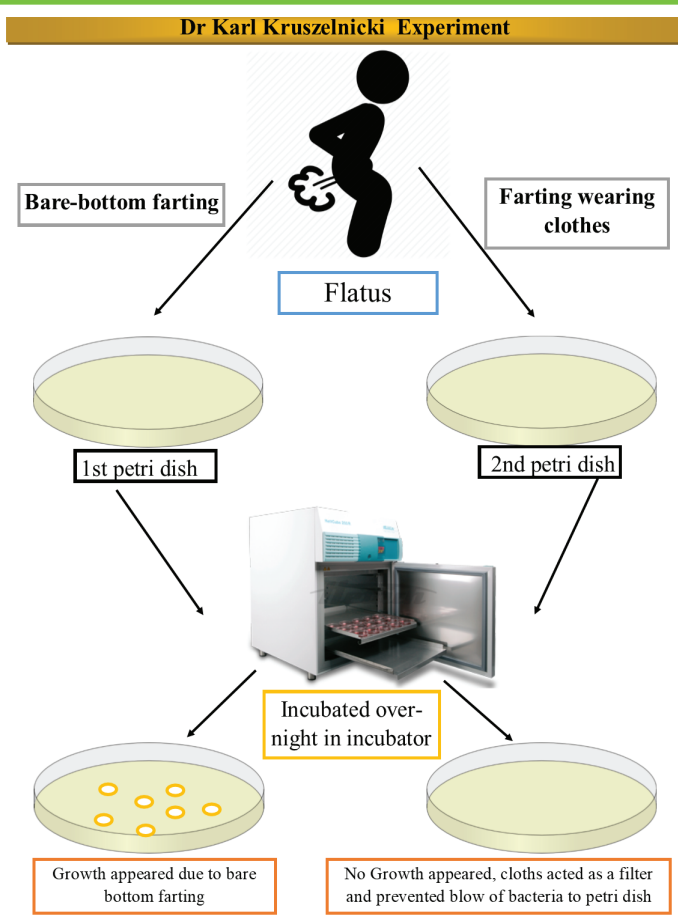

Figure 4. Dr karl's experiment designed for to check whether bare-bottom farting transmits microbes or not

asked his colleague to break out wind directly into petri dishes keeping at a 5 centimeters distance, first fully clothed and then with his trousers down. He keeps the petri dishes overnight in an incubator. The observation was shocking, the flatus that were directly passed to the petri dishes with trousers down, sprouted two types of bacteria one from the gut and the other from the skin. No growth was observed in the petri dish that was exposed to flatus wearing trousers. He concluded that wearing trousers acted as a filter that is why there is no growth observed in the second petri plate. He further deducted that enteric zone observed in the first Petri dish was due to the direct flatus, the fart blew some normal micro flora of buttocks skin blasted into the petri dish. Further study revealed the observed bacteria were not harmful. So therefore, it seems, that flatus may cause infection if the emitter is infected and naked, but not if he or she is clothed. Shown in figure 4.

Medical and health related professionals are cautioned about the new and interesting information to take it as a fact and evidence. While it is not something to believe so quickly but it needs some solid research to confirm farting as a risk for transmission of COVID-19. Regardless of the information whether farting is a risk for transmission of COVID-19, as the viral detection in feces is confirmed so there is a possibility that farting could be a risk for transmission.

In light of the above discussion, we all need good bathroom hygiene. The CDC reminds us that infectious diseases may spread in many ways, such as through mouth, nose, eyes, food, water, broken skin, genital fluids, sexual contact and even through feces.

\section{Prevention and Management}

1. Social distancing is the best way to slow down the spread of COVID-19. There are a few ways to do it [37]. 
2. Avoid travel, do not get out of your home unnecessarily, if going then wear a mask and keep 6 feet distance from others.

3. Avoid working in organization or company and if possible, work from home.

4. Avoid physical contact or visits with friends and family and use phone for communication [38].

5. Make a habit of washing your hands before and after the meal for $20 \mathrm{sec}$ with soap, take great care of washing your hands after attending toilet.

6. Avoid unnecessary shopping, groceries or drugs and other daily usage things should be ordered online.

7. Avoid close contact with pets, their waste and toys they touched.

8. Don't share your personal items like towels, utensils etc.

9. Clean and disinfect the surfaces frequently like phone, tables, doorknobs etc.

10. The infected people must self-quarantine in a separate room to stop the spread of coronavirus to healthy individuals.

11. Gastrointestinal symptoms in COVID-19 infection such as diarrhea could be treated by available medicine used for it.

12. Bare-bottom farting should be avoided in proximity with others in case of infection. So far, there is no vaccine for prevention of COVID-19, but some potential vaccines are being tested or under trial [39] as shown in table 2. These vaccines will be available soon to treat or prevent COVID-19 pandemic. Some experimental drugs are also being tested such as chloroquine and hydroxychloroquine [40]. Convalescent sera are the current available best options as there is no vaccine so far [41]. If the situation worsens call the doctor. Many countries around the world have limited large gatherings by closing markets, shopping malls, schools, universities, restaurants, and theaters [42]. These measures might be extreme. But according to health professionals it is the only way to slow down the spread of COVID-19.

As of yet there are no vaccines, but hopes are alive. Prevention is better than cure. We have only this option. By taking precautionary measures we can compete with COVID-19.

\section{Conclusion}

Diarrhea, vomiting and abdominal discomfort are frequent symptoms in patients infected with SARS-CoV-2. Increasing evidences and the detection of viral sequences in stools and gastrointestinal manifestations indicating the possible oral-fecal transmission and this route of transmission could be a potential risk. Asymptomatic spread is more alarming. Proper care is

\section{Table 2. Composition of Flatus}

\begin{tabular}{|l|l|}
\hline Vaccine & Phase \\
\hline DNA & Phase II \\
\hline Viral vector & Phase I \\
\hline Subunit & Preclinical stage \\
\hline Inactivated & Preclinical stage \\
\hline Live-attenuated virus & Preclinical stage \\
\hline Virus-like particles & Preclinical stage \\
\hline
\end{tabular}

needed. An infected person can transmit infection to 2 healthy individuals. Bacteria spreads through bare-bottom farting so the virus could also. Close contact with feces of humans and animals and bare-bottom farting should be avoided. To minimize the oral-fecal transmission hands must be washed before and after attending toilet with soap for $20 \mathrm{sec}$. Moreover, the virus can live for hours on surface proper disinfection and prevention must be adapted. Keep social distancing and stay home, stay safe.

\section{Declarations of interest}

The authors declare no conflicts of interest.

This study received no external funding.

\section{Acknowledgements}

We are thankful to Department of Biotechnology, Quaid-i-Azam University, Islamabad, Pakistan for their support. The authors state that they abide by the "Requirements for Ethical Publishing in Biomedical Journals" [43].

\section{References}

1. Ji Y, Ma Z, Peppelenbosch MP, Pan Q. Potential association between COVID-19 mortality and health-care resource availability. The Lancet Global Health. 2020;8(4):e480. http://dx.doi.org/10.1016/S2214-109X(20)30068-1

2. Jan H, Faisal S, Khan A, Khan S, Usman H, Liaqat R, et al. COVID-19: Review of Epidemiology and Potential Treatments Against 2019 Nove Coronavirus. Discoveries. 2020;8(2). http://dx.doi.org/10.15190/d.2020.5

3. Prompetchara E, Ketloy C, Palaga T. Immune responses in COVID-19 and potential vaccines: Lessons learned from SARS and MERS epidemic. Asian Pacific Journal of Allergy and Immunology. 2020;38(1):1-9.

4. Wang D, Hu B, Hu C, Zhu F, Liu X, Zhang J, et al. Clinical Characteristics of 138 Hospitalized Patients With 2019 Novel Coronavirus-Infected Pneumonia in Wuhan, China. JAMA. 2020. http://dx.doi.org/10.1001/ jama.2020.1585

5. Leung WK, To KF, Chan PK, Chan HL, Wu AK, Lee N, et al. Enteric involvement of severe acute respiratory syndrome-associated coronavirus infection. Gastroenterology. 2003;125(4):1011-7. DOI: 10.1016/s00165085(03)01215-0

6. Holshue ML, DeBolt C, Lindquist S, Lofy KH, Wiesman J, Bruce H, et al. First case of 2019 novel coronavirus in the United States. New England Journal of Medicine. 2020. http://dx.doi.org/10.1056/NEJMoa2001191

7. To KK, Tsang OT, Chik-Yan Yip C, Chan KH, Wu TC, Chan JMC, et al. Consistent detection of 2019 novel coronavirus in saliva. Clinical infectious diseases : an official publication of the Infectious Diseases Society of America. 2020. http://dx.doi.org/10.1093/cid/ciaa149

8. Bauch CT, Lloyd-Smith JO, Coffee MP, Galvani AP. Dynamically modeling SARS and other newly emerging respiratory illnesses: past, present, and future. Epidemiology (Cambridge, Mass). 2005;16(6):791-801. http:// dx.doi.org/10.1097/01.ede.0000181633.80269.4c

9. Wang J, Tang K, Feng K, Lv W. High temperature and high humidity reduce the transmission of COVID-19. Available at SSRN 3551767. 2020. http:// dx.doi.org/10.2139/ssrn.3551767

10. Li Q, Guan X, Wu P, Wang X, Zhou L, Tong Y, et al. Early transmission dynamics in Wuhan, China, of novel coronavirus-infected pneumonia. New England Journal of Medicine. 2020. http://dx.doi.org/10.1056/ NEJMoa2001316

11. Phan LT, Nguyen TV, Luong QC, Nguyen TV, Nguyen HT, Le HQ, et al. Importation and human-to-human transmission of a novel coronavirus in Vietnam. New England Journal of Medicine. 2020;382(9):872-4. http:// dx.doi.org/10.1056/NEJMc2001272

12. Chen C, Gao G, Xu Y, Pu L, Wang Q, Wang L, et al. SARS-CoV-2-positive sputum and feces after conversion of pharyngeal samples in patients with COVID-19. Annals of Internal Medicine. 2020. http://dx.doi.org/10.7326/ M20-0991

13. Bai Y, Yao L, Wei T, Tian F, Jin DY, Chen L, et al. Presumed Asymptomatic Carrier Transmission of COVID-19. JAMA. 2020. http://dx.doi.org/10.1001/ jama.2020.2565

14. Ebrahim SH, Ahmed QA, Gozzer E, Schlagenhauf P, Memish ZA. Covid-19 and community mitigation strategies in a pandemic. British Medical Journal Publishing Group; 2020. http://dx.doi.org/10.1136/bmj.m1066

15. Price K, Lewis J, Wyatt G, Fenwick G. Review article FlatulenceCauses, relation to diet and remedies. Food/Nahrung. 1988;32(6):609-26. http://dx.doi.org/10.1002/food.19880320626

16. Tangerman A. Measurement and biological significance of the volatile sulfur compounds hydrogen sulfide, methanethiol and dimethyl sulfide in various biological matrices. Journal of Chromatography B. 2009;877(28):3366-77. http://dx.doi.org/10.1016/j.jchromb.2009.05.026 
17. Tomlin J, Lowis C, Read N. Investigation of normal flatus production in healthy volunteers. Gut. 1991;32(6):665-9. http://dx.doi.org/10.1136/ gut.32.6.665

18. Prasad GA, Alexander JA, Schleck CD, Zinsmeister AR, Smyrk TC, Elias $\mathrm{RM}$, et al. Epidemiology of eosinophilic esophagitis over three decades in Olmsted County, Minnesota. Clinical Gastroenterology and Hepatology. 2009;7(10):1055-61. http://dx.doi.org/10.1016/j.cgh.2009.06.023

19. Passos M, Serra J, Azpiroz F, Tremolaterra F, Malagelada J. Impaired reflex control of intestinal gas transit in patients with abdominal bloating. Gut. 2005;54(3):344-8. http://dx.doi.org/10.1136/gut.2003.038158

20. Suarez FL, Levitt MD. An understanding of excessive intestinal gas. Current Gastroenterology Reports. 2000;2(5):413-9. http://dx.doi.org/10.1007/ s11894-000-0042-8

21. Bell A, Ciclitira PJ. Managing bloating, flatus and flatulence. The Practitioner. 2000;244(1609):301-4, 6, 8-11. PMID: 10892051

22. Pouderoux P, Ergun GA, Lin S, Kahrilas PJ. Esophageal bolus transit imaged by ultrafast computerized tomography. Gastroenterology. 1996;110(5):1422-8. http://dx.doi.org/10.1053/gast.1996.v110.pm8613047

23. Levitt MD, Furne J, Aeolus M, Suarez FL. Evaluation of an extremely flatulent patient: case report and proposed diagnostic and therapeutic approach. The American Journal of Gastroenterology. 1998;93(11):227681. http://dx.doi.org/10.1016/S0002-9270(98)00516-4

24. Levitt MD. Volume and composition of human intestinal gas determined by means of an intestinal washout technic. New England Journal of Medicine. 1971;284(25):1394-8. http://dx.doi.org/10.1056/NEJM197106242842502

25. Richards E, Steggerda F. Production and inhibition of gas in various regions in the intestine of the dog. Proceedings of the Society for Experimental Biology and Medicine. 1966;122(2):573-6. http://dx.doi.org/10.3181/00379727-122-31194

26. Suarez FL, Springfield J, Furne JK, Lohrmann TT, Kerr PS, Levitt MD. Gas production in humans ingesting a soybean flour derived from beans naturally low in oligosaccharides. The American Journal of Clinical Nutrition. 1999;69(1):135-9. http://dx.doi.org/10.1093/ajcn/69.1.135

27. Suarez F, Springfield J, Levitt MD. Identification of gases responsible for the odour of human flatus and evaluation of a device purported to reduce this odour. Gut. 1998;43(1):100-4. http://dx.doi.org/10.1136/gut.43.1.100

28. Mercer B. How do you light a fart?: and 150 other essential things every guy should know about science: Simon and Schuster; 2009.

29. MillerTL, Wolin M, de Macario EC, Macario A. Isolation of Methanobrevibacter smithii from human feces. Appl Environ Microbiol. 1982;43(1):227-32. http://dx.doi.org/10.1128/AEM.43.1.227-232.1982

30. Pimentel M, Gunsalus RP, Rao SS, Zhang H. Methanogens in human health and disease. The American Journal of Gastroenterology Supplements. 2012;1(1):28. http://dx.doi.org/10.1038/ajgsup.2012.6

31. Roudebush P. Flatulence: Causes and Management Options. Compendium. 2001;23(12):1075-82.

32. Reddy N, Salunkhe D, Sharma R. Flatulence in rats following ingestion of cooked and germinated black gram and a fermented product of black gram and rice blend. Journal of Food Science. 1980;45(5):1161-4. http://dx.doi.org/10.1111/j.1365-2621.1980.tb06511.x

33. Rao SS. Belching, bloating, and flatulence: how to help patients who have troublesome abdominal gas. Postgraduate Medicine. 1997;101(4):263-78. http://dx.doi.org/10.3810/pgm.1997.04.208

34. Song Y, Liu P, Shi X, Chu Y, Zhang J, Xia J, et al. SARS-CoV-2 induced diarrhoea as onset symptom in patient with COVID-19. Gut. 2020;69(6):1143-4. http://dx.doi.org/10.1136/gutjnl-2020-320891

35. Pan L, Mu M, Yang P, Sun Y, Wang R, Yan J, et al. Clinical characteristics of COVID-19 patients with digestive symptoms in Hubei, China: a descriptive, cross-sectional, multicenter study. The American Journal of Gastroenterology. 2020;115. http://dx.doi.org/10.14309/ ajg.0000000000000620

36. Lin L, Jiang X, Zhang Z, Huang S, Zhang Z, Fang Z, et al. Gastrointestinal symptoms of 95 cases with SARS-CoV-2 infection. Gut. 2020;69(6):9971001. http://dx.doi.org/10.1136/gutjnl-2020-321013

37. Greenstone M, Nigam V. Does social distancing matter? University of Chicago, Becker Friedman Institute for Economics Working Paper 2020(2020-26). http://dx.doi.org/10.2139/ssrn.3561244

38. Wilder-Smith A, Freedman DO. Isolation, quarantine, social distancing and community containment: pivotal role for old-style public health measures in the novel coronavirus (2019-nCoV) outbreak. Journal of travel medicine. 2020;27(2):taaa020. http://dx.doi.org/10.1093/jtm/taaa020

39. D'Amico F, Baumgart DC, Danese S, Peyrin-Biroulet L. Diarrhea during COVID-19 infection: pathogenesis, epidemiology, prevention and management. Clinical Gastroenterology and Hepatology. 2020. http://dx.doi.org/10.1016/j.cgh.2020.04.001

40. Colson P, Rolain J-M, Lagier J-C, Brouqui P, Raoult D. Chloroquine and hydroxychloroquine as available weapons to fight COVID-19. Int J Antimicrob Agents. 2020;105932(10.1016). http://dx.doi.org/10.1016/j.ijantimicag.2020.105932

41. Casadevall A, Pirofski L-a. The convalescent sera option for containing COVID-19. Journal of Clinical Investigation. 2020;130(4):1545-8. http://dx.doi.org/10.1172/JCl138003
42. Hartl T, Wälde K, Weber E. Measuring the impact of the German public shutdown on the spread of COVID19. Covid economics, Vetted and realtime papers, CEPR press. 2020;1:25-32.

43. Shewan LG, Coats AJS, Henein M, Authors' Responsibilities and Ethica Publishing. International Cardiovascular Forum Journal; 2018;13:3-4, DOI: 10.17987/icfj.v13i0.525 